\title{
AEROMAGNETIC MAP OF THE SAVANNAH RIVER PLANT AREA SOUTH CAROLINA AND GEORGIA \\ By
}

A. J. Petty, F. A. Petrafeso, and F. C. Moore, Jr.

GEOPHYSICAL INVESTIGATIONS

MAP GP-489

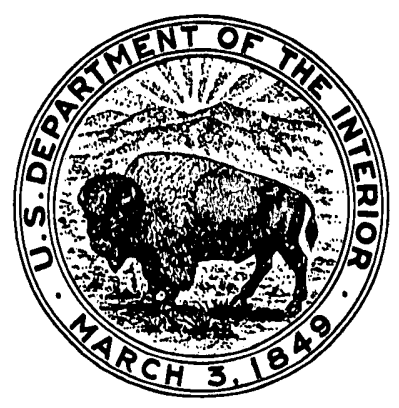

